\title{
ЯЗЫКОВЫЕ И КУЛЬТУРНЫЕ ОСОБЕННОСТИ РУССКОГО ПЕРЕВОДА КНИГИ МАРИУША ЩИГЕЛА GOTTLAND
}

\section{Language and Cultural Features of the Russian Translation of the book "Gottland" by Mariusz Szczygiet}

Keywords: Mariusz Szczygiet, reportage, translation, reportage language, cultural realia

Contact: Uniwersytet Śląskiw Katowicach; adamczyk.dawid93@gmail.com

Если обратить внимание на упрощенный стереотипный образ Чехии, то польские и русские начинающие любители этой страны считают, что чехи - это прежде всего жизнерадостные и симпатичные знатоки пива, живущие в старинной Праге или живописных городках. Уже давно символами этой радостной краины стали знаменитые персонажи XX-ого века - «чешский Пресли» Карел Готт, президент Вацлав Гавел или вратарь Петр Чех. Кроме того, многие помнят солдата Швейка или потешного Крота, переживающего разные перепетии на экране телевизора. Можно даже прийти к выводу, что в Чехии никогда не происходило ничто бурное или драматическое, а ее атмосфера способствует, по главной мере, тому, чтобы неспешно посещать разные места, наслаждаться ландшафтом и расслабляться за чашкой вкусного, золотистого, алкогольного напитка.

Неудивительно, что постоянно увеличивается группа усердных чехофилов. Среди них однако все чаще появляются люди, которые пытаются заглянуть за описанный идиллический занавес и более углубленно изучить увлекательную, а нередко и мрачную, историю этой части славянского мира. Одним из них является польский репортер и писатель Мариуш Щигел - автор сборника репортажей Gottland (рус. Готтленд), посвященного лицам, объектам, событиям и культурно-социальным явлениям, которые на историческом фоне отражают чешский менталитет.

Gottland, опубликованный в 2006 году издательством «Wydawnictwo Czarne», которое ценят польские поклонники жанра репортажа, - это первое, но не последнее произведение Щигела на тему Чешской Республики (позже он 
написал книги Zrób sobie raj и Láska nebeská), однако только оно было издано на русском языке. Упомянутый сборник добился большого успеха, в связи с чем писатель получил Премию Европейского Союза в области литературы, а польские читатели избрали его лауреатом литературной премии «Нике» (электронный pecypc: Instytut Reportażu).

Для польского читателя Gottland становится источником для более близкого знакомства с южным соседом, особенно в случае готовности адресата совершить своеобразное путешествие по лабиринту камерных и иногда неизведанных фактов из новейшей чешской истории. В свою очередь, для чешского получателя его перевод является зеркалом, показывающим, как другие воспринимают его страну. В то же время возникает вопрос: Как охарактеризовать позицию этой книги в русском литературном пространстве?

По нашему мнению, с одной стороны, она становится интересным читательским опытом для тех, кто интересуется Чехией, но с другой - это существенное дополнение диапазона переведенных на русский язык произведений представителей польской школы репортажа - Рышарда Купущинского, Мариуша Вилька или Яцека Хуго-Бадера.

Главная разница между автором Готтленда и названными писателями заключается в том, что Россия никогда на оказалась в центре его интересов. Отметим, что русский чиататель имеет возможность познакомиться с работой Щигела благодаря труду переводчицы польской и чешской литературы - Полины Сергеевны Козеренко.

Независимо от языковой версии, читатель уже при первом контакте с книгой может быть заинтригован по поводу ее заглавия. Во-первых, оно провоцирует религиозным контекстом (Готтленд - Божья земля). Во-вторых, сборник репортажей назван так же, как французский музей Карела Готта, построенный за несколько лет до смерти певца (Mroczek 2011: 205).

Особенного внимания заслуживает также тематический набор репортажей, в котором почти полностью отсутствуют сведения, встречаемые в исторических и культурологических учебниках. Здесь нет также отсылки на содержание страноведческих интернет-сайтов, представляющих популярнейшие чешские достопримечательности и развлечения.

Вместе с тем, на основании почерпнутых из жизни сюжетов, раскрытых и описанных Щигелом, читатель знакомиться со многими интересными людьми. В частности, с производителем обуви Томашем Батей, создавшим полностью контролируемый город, скульптором Отакаром Швецем - автором величайшего 
в мире памятника Сталину, племянницей Франца Кафки, а также Мартой Кубишовой - певицей, жизнь и карьера которой были сломаны коммунистическим режимом. Все персонажи сильно вплетены в трудные времена Чехословакии и Чехии - страны ужаса и гротеска, не имеющей ничего общего с образом, представленным в первом абзаце нашей работы. Посредством представления ярких человеческих судеб автор рассказывает о действительности, где за простые, казалось бы, решения люди платили высокие цены.

В введении, оказавшимся в русской версии книги, польский публицист Михал Радговский пишет: «Интересна стилистика репортажей: короткие рубленые фразы, с ювелирной точностью выстроенная кульминация, резкие столкновения противоречивых ситуаций и настроений, прыжки во времени и пространстве» (Радговский 2009: 4).

Читая Готтленд, действительно путешествуем как по чужой стране, так и во времени. Это связано с тематической характеристикой и авторским замыслом - избегать замечаний и показывать чешский менталитет с помощью соответствующего подбора описываемых фактов, что в большей степени позволяет получателю текста самостоятельно делать выводы.

Коммуникативно-прагматическя текстовая специфика в этом случае опирается на фактографическую разработку описываемых автором историей. При этом, здесь не сталкиваемся с информационным избытком благодаря избирательности и четкости передаваемых сведений - одним из главных показателей публицистики (Rejter 2000: 27-28). Осуществление этой авторской концепции требует использования определенных языковых приемов, образующих стиль произведения. То же утверждение касается перевода, который должен, кроме содержания, отображать стилистические особенности исходного текста в рамках другого языка. Переводчице, в случае Готтленда удалось достигнуть этой цели. В качестве иллюстраций приводим следующие фрагменты из польской и русской версиий книги:

Tomáš patrzy na resztki skór $i$ w rozpaczy wpada na najważniejsza zasadę swojego życia: z wady zawsze zrobić zaletę.

Skoro nie stać ich na skóry, trzeba szyć buty z tego, co jest: z plótna. Płótno niewiele kosztuje, a z resztek skóry można zrobić podeszwy. W ten sposób Bata wymyśla jeden z hitów nadchodzacego wieku: plócienne buty na skórzanej podeszwie. Z Wiednia przywozi kilka tysięcy zamówień zebranych w jeden dzień. Buty nazywane sa przez ludzi „,batovkami”. 
Dzięki nim buduje pierwsza swoja fabryczkę: na dwustu metrach kwadratowych pracuje pięćdziesięciu mężczyzn (Szczygieł 2006: 8).

Томаш смотрит на остатки кожи и с отчаяния придумывает свой самый важный жизненный приниип - недостатки всегда превращать в достоинства.

Раз у них нет денег на кожу, нужно шить обувь из того, что есть, - из полотна. Полотно стоит недорого, а из остатков кожи можно делать подошвы. Так Батя изобретает один из хитов приближающегося столетия полотняные туфли на кожаной подошве. Из Вены он привозит несколько тысяч заказов, полученных за один день. Туфли в народе называют «батёвками».

Благодаря им он строит свою первую небольшую фабрику - на двухстах квадратных метрах работают пятьдесят мужчин (Щигел 2009: 12-13).

Gdy zapraszat Lidę na zjazd, Magda Geobbels - ideat kobiety III Rzeszy-miała trzydzieści pięć lat... (53)

Когда он приглашал Лиду на съезд, Магде Геббельс - идеалу женщины Третьего рейха - было тридиать пять лет... (102)

В оригинале отсутствуют фигуральные экспрессивные предложения, вместо чего преобладают синтаксические конструкции, состоящие максимально из трех частей, причем они резко разделены простыми союзами или знаками препинания. При этом заметно частотное использование двоеточия, которое чаще всего предшествует объяснительному члену предложения, а также тире, выделяющего, кроме высказываний персонажей, вводные части. Кроме того, текст лишен поэтических эпитетов и эмоционально-оценочных выражений. Такая текстовая архитектоника, вместе со структурой, напоминающей хронологический ряд передачи информации в прессе, указывает на то, что для автора важнее всего описывать очередные факты и двигать рассказ вперед, чем побуждать эстетическую впечатлительность.

Писательский стиль Щигела не представляет собой вызова в области межъязыкового посредничества. В случае русского перевода он не требует значительных преобразований. Конечно, есть разницы, однако они имеют более детальный характер, напр. применение предлога $c$, указывающего на причину вместо польского $w$, употребленного в значении 'быть в состоянии' (w rozpaczy c отчаяния) или модификации синонимического характера (niewiele kosztuje cmoum недорого). Более того, русский язык дает широкую возможность 
употребления тире, выполняющего те же самые функции. Этот знак препинания замещает также двоеточия.

Размещение в русском переводе чешских бытовых или исторических реалий также не требовало поисков функциональных эквивалентов, так как общественные и культурные явления были описаны Щигелом с учетом перцептивных способностей довольно широкой публики.

Номинации, относящиеся к описываемому времени и пространству, которые в польском тексте приобрели оригинальную чешскую запись (напр: имена и фамилии, заглавия, названия зданий и др.), были транскрибированы согласно принципу переноса записанных на латыни названий в кириллицу: Olbram Zoubek - Олбрам Зоубек, „Rudé právo” - «Pуде право», Pałac Lucerna Двореи Лючерна.

Исключением от вышеуказанной закономерности является перевод фрагмента, смысл которого заключается в описании языковых нюансов, соотносящихся с известными чешскими литературными сюжетами. В следующем фрагменте исходные названия были оставлены в своем оригинальном написании, что дало возможность передать намек на словообразовательные аналогии:

(...) vodárna to po czesku miejsce, gdzie oczyszcza się wodę, octárna - gdzie produkuje ocet. A więc istnieje miejsce, gdzie robi się coś z Kafka.

kafkárna to jest coś, o czym wszyscy wiedza, ale wiedza też, że nic nie da się z tym zrobić.

„, To jest heca i gdyby człowiek nie brat tego jako hecy, to naprawde nie wiadomo, co by było”. Albo: „, To jest coś bardzo gtupiego, ale musi być”. „Na pewno myli to pani ze švejkárna, a $i$ to źle, bo nie ma takiego słowa. Jest za to švejkovina, czyli zachowywanie się jak Szwejk. Tylko to jest zupetnie coś innego niz kafkárna” (194).

(...) « vodárna по-чешски - место, где очищуают воду, осtárna - где производят уксус. Следовательно, существует место, где что-то делают с Кафкой».

(...) kafkárna - это нечто, о чем все знают, но одновременно понимают, что ничего с этим сделать нельзя. Главное - не следует этому удивляться. Просто принять к сведению.

«Это нелепицุа. И если не относиться к этому, как к нелепище, еще неизвестно, что может произойти». Или: «Это что-то очень глупое, но должно существовать». «Bbl, вероятно, путаете это со словом švejkárna, что тоже 
неправильно, поскольку такого слова нет. Есть švejkovina, то есть манера вести себя, так Швейк. Только это совсем не то, что kafkárna» (359-360).

Последний аспект нашей работы касается не совершенной переводчицей верификации аутентичности некоторых сведений, оказавшихся в оригинальной версии. Как мы уже отмечали, Козеренко работает также с чешскими текстами, что в случае передачи Готтленда открывает путь к более внимательному толкованию содержания оригинала. Следуюший фрагмент указывает на то, что переводчица полагается только на авторскую версию, не обращая внимания на то, что чешский перевод был опубликован перед русским вариантом:

Wtedy niespodziewanie w catej Czechostowacji pojawiaja się ulotki:

NIE JESTEM BOGATY

NIE JESTEM BIEDNY

NIE JESTEM BANKRUTEM

DAJĘ DOBRE PENSJE

PŁACE UCZCIWIE WSZYSTKIE PODATKI

ROBIE DOBRE BUTY

PROSZE SIĘ PRZEKONAĆ

Tomáš Bat’a (14)

Тогда вдруг по всей Чехословакии появляются листовки:

Я НЕ БОГАТ

Я НЕ БЕДЕН

Я НЕ БАНКРОТ

Я ПЛАЧУ ХОРОШИЕ ЗАРПЛАТЫ

Я ЧЕСТНО ПЛАЧУ ВСЕ НАЛОГИ

Я ДЕЛАЮ ХОРОШУЮ ОБУВЬ

САМИ МОЖЕТЕ УБЕДИТЬСЯ

Томаш Батя (26-27) 
Приведенный фрагмент является интертекстом, переведенным Щигелом с чешского языка:

\author{
NEJSEM BOHÁC̆EM \\ NEJSEM BANKROTÁR̆EM \\ PLATÍM NEJVY Y̌S̆Í MZDY \\ PLATÍM $\check{\boldsymbol{R}} \boldsymbol{A} \boldsymbol{D} \boldsymbol{N} \check{\boldsymbol{E}} D A ́ N \check{E}$ \\ $D \check{E} L A ́ M$ DOB $\check{\boldsymbol{R}}$ E BOTY \\ $P \check{R} E V \check{E} D \check{C} T \check{E} S E$

\section{Tomáš Bat’a}

Автор модифицировал содержание листовки, рекламирующей предприятие Бати. Хелена Стахова, переводчица чешской версии книги, в отличие от Козеренко, решила сопоставить этот фрагмент с его источником и поместить в тексте первичный вариант (Mroczek 2011: 208).

Кроме грамматических изменений, появляется предложение NIE JESTEM BIEDNY - Я HE БЕДЕН, которое отсутсвует в источнике обсуждаемого интертекста. Здесь имеем дело с авторской ошибкой. Более того, сложно ее оправдать даже по поводу необходимых смысловых модификаций. Если кто-то утверждает, что он не богат и не банкрот, то зачем подчеркивать, что он не беден?

Возможно, что по сравнении исходного текста с чешским переводом обнаружаться и другие не до конца проверенные сведения, однако подчеркнем, что автор не добавляет к введенным в текст цитатам и интертекстуальным единицам библиографических описаний. В связи с этим переводчица была паставлена перед выбором: проверять или доверять автору. Она выбрала вторую возможность и была вправе принять такое решение.

Рассматривая в разных аспектах вопрос языковой и культурной специфики перевода Готтленда, можно прийти к выводу о том, что главная задача при его осуществлении заключалась в том, чтобы воссоздать структуру текста и языковые приемы, формирующие писательский стиль автора. Ведь, как мы раньше отметили, художественная ценность произведения Щигела не опирается на экспрессивную литературную концепцию или яркие культурологические анализы. Она восходит к журналисткому труду, который заключается в том, чтобы использовать понятный широкой публике языковой стиль, не оценивать, отдать голос персонажам, подбирать интересные и значимые факты, а прежде 
всего - оставить читателю пространство для выработки собственного мнения. В таком случае переводчице остается следовать за автором, что видно в русском переводе обсуждаемой книги.

\section{Summary}

The colletion of reportages by Mariusz Szczygieł titled Gottland is devoted to the people, objects and events and socio-cultural phenomens which on historical basis reflect Czech mentality. For the Polish reader it became fascinative source for deeper acquaintance with southern neighbour. Reporter give up from the description of well known aspects of Czech culture, brought closer to the readers book nuanses, sometimes not examined even from the Czechs themselves. For the Czech reader in turn, the translation of Gottland became the mirrow in which he can see how other people percive him. In the following paper there were analysed language features of writer style and the way of their recreation in translation language and also the translation of cultural realia which enabled to draw conclusions in reference to the assesment of Russian realization of the version of the work of the mentioned author.

\section{Литература}

Радговкий, М. Чешская Панорама. In: Щигел, М. Готтленд. Москва: Новое литературное обозрение, 2009, с. 3-8.

Щигел, М. Готтленд. Москва: Новое литературное обозрение, 2009.

Mroczek, I. „Gottland” Mariusza Szczygła w czeskim przekładzie i jego czeska recepcja: przypadek Ludvika Vaculika. Przekłady Literatur Słowiańskich. 2011 (2), c. 203-212.

Rejter, A. Kształtowanie się gatunku reportażu podróżniczego w perspektywie stylistycznej i pragmatycznej. Katowice: Wydawnistwo Uniwersytetu Śląskiego, 2000.

Szczygiel, M. Gottland. Wołowiec: Wydawnictwo Czarne, 2006.

\section{Интернет-источники}

Режим доступа: http://instytutr.pl/pl/impresariat/mariusz-szczygiel/ (2020-04-26). 